\title{
Communication
}

[Comunicação]

\section{A longitudinal study of porcine proliferative enteropathy in a commercial pig farm in Yucatan Mexico}

\author{
[Estudo longitudinal da enteropatia proliferativa suina em uma granja de suínos no México]
}

\author{
J.C. Rodríguez, M. Alvarez, L. Rodríguez, J.C. Segura
}

Facultad de Medicina Veterinaria y Zootecnia. Universidad Autónoma de Yucatán Apdo. Postal 4-116 Km 15.5. Carretera Mérida-Xmatkuil

Mérida Yucatán, México

Porcine proliferative enteropathy (PPE) is an emergent disease caused by the bacterium Lawsonia intracellularis characterised by variable clinical signs, but with visible pathonogmonic lesions at the necropsy (McOrist, Gebhart, 1999). This pathology affects farms with modern systems of production, and pigs from weaning to market and replacements. The disease is world wide distributed, with herd and animal prevalences of 15 to $35 \%$ and 15 to $20 \%$, respectively. PPE causes economical losses to the pig industry by mortality, increasing of feed consumption, pigs with low body weight and more days to market (Winkelman et al., 1998).

In order to establish control programs for this disease information on the mechanism of transmission and survival capacity of the bacterium in the environment, the efficacy (invitro and in-vivo) of available antibiotics, and disease shedding pattern are necessary (McOrist et al., 1995). In Mexico, few studies on $L$. intracellularis were reported.

The objective of this study was to describe the shedding pattern of $L$. intracellularis in fattening pigs under field conditions and determine the effect of positive and negative pigs to $L$. intracellularis on body weight gain.

A longitudinal epidemiological study was conducted from November 1998 to May 1999 in a multi-site farm in Yucatan, Mexico. Yucatan is located in the Southeast of Mexico between coordinates $19^{\circ} 30^{\prime}$ and $21^{\circ} 35^{\prime}$ North latitude and $90^{\circ} 40^{\prime}$ westwards Greenwich Meridian. The climate of the region is tropical humid with $70 \%$ of the rain falling during summer. In the hottest months (March to May) the temperature reaches between $35^{\circ} \mathrm{C}$ and $40^{\circ} \mathrm{C}$ (mean $26.6^{\circ} \mathrm{C}$ ). Relative humidity varies from 65 to $100 \%$ (mean $78 \%$ ) and annual rainfall varies from 415 to $1290 \mathrm{~mm}$ (mean 900) depending on the area (García, 1988). The multi-site farm consisted of three sites geographically separated with all-in all-out system. This farm was located in a low-density pig-farm area.

Fifty-six negative pigs to $L$. intracellularis were used. The number of pigs was calculated using an expected prevalence of $5 \%$, a confidence level of $95 \%$ and a population of fattening pigs of 2000 (Martin et al., 1987). Pigs negative to the polymerase chain reaction (PCR) test at the start of the study were used. In the farm, 12 negative sows were selected, choosing five piglets from the first eight sows and four from the rest. Piglets were randomly chosen using a random table and weighted at weaning ( 21 days) and three days before marketing time. Body weight gain during the whole period of study was obtained subtracting the weaning weight from the final weight.

Pigs were sampled 12 times from birth to week 23 of age (Table 1). During each sampling, feces (1g) were collected directly from pig's rectum using sterile loops. Fecal samples were kept in

Recebido para publicação em 4 de abril de 2003

Recebido para publicação, após modificações, em 11 de dezembro de 2003

E-mail rbuenfil@tunku.uady.mx 
polyethylene bags, identified, conserved at $4^{\circ} \mathrm{C}$ for transportation to the laboratory and then frozen at $-20^{\circ} \mathrm{C}$ until testing. The bacterium was detected by PCR test (McOrist et al., 1994). The DNA was extracted, using a guanidine thiocyanate nucleic acid extraction kit. Two and half milliliters of the primer set, 5'-TATGGCTGTCAAACACTCCG-3' and $2.5 \mathrm{ml}$ of the primer 5'-TGAAGGTATTGGTATTCTCC-3', was used for DNA amplifications. For the first cycle, parameters were $93^{\circ} \mathrm{C}$ for five minutes, $55^{\circ} \mathrm{C}$ for 45 seconds, and $72^{\circ} \mathrm{C}$ for 45 seconds. Thirty-eight cycles were performed at the previously mentioned temperatures for 45 seconds per temperature setting. The final cycle was performed at $93^{\circ} \mathrm{C}$ for 45 seconds, $55^{\circ} \mathrm{C}$ for 45 seconds, and $72^{\circ} \mathrm{C}$ for five minutes. The PCR-positive samples produced a 319-bp product detected by gel elecrophoresis on a $1 \%$ agarose gel. The DNA was stained by ethidium bromide and visualized under ultraviolet light. The PCR test had a sensitivity and specificity of $39 \%$ and $98 \%$, respectively.

Table 1. Feces excretion pattern of Lawsonia intracellularis in pigs from birth to market weight in a multi-site farm in Yucatan Mexico

\begin{tabular}{lcccccc}
\hline Period & Age (week) & Exposed & PCR $(+)$ & $\begin{array}{c}\text { Cumulative } \\
\text { incidence }(\%)\end{array}$ & Pig-week at risk & $\begin{array}{c}\text { IDR } \\
\text { (x100 pig-week at risk }\end{array}$ \\
\hline Lactating & 1 & 56 & 0 & 0 & 56 & 0 \\
& 3 & $53^{*}$ & 2 & 3.57 & 109 & 1.83 \\
Growing & 6 & 53 & 0 & 3.57 & 159 & 0 \\
& 7 & 50 & 3 & 8.93 & 51.5 & 5.83 \\
& 11 & 44 & 6 & 19.64 & 188 & 3.22 \\
Finishing & 13 & 44 & 0 & 19.64 & 88 & 0 \\
& 15 & 43 & 1 & 21.43 & 87 & 1.15 \\
& 17 & 43 & 0 & 21.43 & 86 & 0 \\
Total & 19 & 42 & 1 & 23.21 & 85 & 0 \\
& 21 & 42 & 0 & 23.21 & 84 & 0 \\
\hline
\end{tabular}

* one pig died; $\mathrm{PCR}=$ polymerase chain reaction; IDR= incidence density rate.

A pig shedding L. intracellularis for the first time, as detected by the PCR test, was considered a case. Cumulative incidence was calculated by dividing the number of positive pigs during the study by the total number of pigs at the start of the study. The incidence density rate was calculated by dividing the number of positive pigs during the study period by the number of pig-week at risk. Pig-week at risk in each sampling period was obtained by subtracting from the number of pigs at the start of the period, half of the new cases, half of the dead pigs within the period and then multiplying the result for the period length in weeks. Body weight gain of positive animals was compared with body weight gain of negative pigs using the $t$ student test (Steel and Torrie, 1985).

Thirteen out of 56 monitored pigs excreted $L$. intracellularis in feces and only one resulted positive twice during the study. The shedding of L. intracellularis was detected from week 3 to 19 of age, observing the highest number of positive pigs at week 11 (Table 1).

The cumulative incidence and overall incidence density rate were $23.2 \%$ and 1.21 pigs per 100 pig-week at risk, respectively (Table 1). The weight gains during the growing period were $107.66 \pm 8.78 \mathrm{~kg}$ and $109.107 \pm 11.3 \mathrm{~kg}$ for the positive and negative pigs, respectively $(\mathrm{P}>0.05)$. Similarly the average daily gains were $0.742 \pm 0.06 \mathrm{~kg}$ and $0.754 \pm 0.07 \mathrm{~kg}$ for the positive and negative pigs, respectively $(\mathrm{P}>0.05)$.

The fact that pigs shed the bacterium from week 3 to 19 indicates that shedding of $L$. intracellularis is occurring during the whole fattening period. Studies in Mexico (RodriguezGuzman, 2001) reported that pigs shed $L$. intracellularis during the whole fattening period. However, the result in which only one pig shed twice the bacterium during the study differs from those of Rodriguez-Guzman (2001) who found, 
in the same region and type of farm, that all of their 59 pigs used shed the bacterium from three to eight times.

The cumulative incidence found in this study (23.2\%) differs from that obtained by RodriguezGuzman (2001) in Yucatan, Mexico, who reported a cumulative incidence of $100 \%$ for pigs raised in a similar farm system. Differences in the cumulative incidences are probably due to the use of antibiotics in this study. As mentioned above, Schwartz et al. (1999) and Walter et al. (2001), in the United States, concluded that the use of antibiotics reduces the fecal shedding of $L$. intracellularis.

The highest number of pigs shedding the bacterium was observed at week 11, whereas, Rodriguez-Guzman (2001) observed a high frequency of positive pigs at week 7. Mapother et al. (1987) and McOrist et al. (1989), mentioned that the incubation period of the bacterium is from two to three weeks, therefore, it is probable that pigs were infected at the piggery. Smith and McOrist (1997), suggested that first-farrowing sows can be infected and shed the bacterium during lactation.

Although this study and that of RodriguezGuzman (2001) were done in the same region and type of farm system the stress associated to transport, mixed of animals and poor health conditions in a farm, can be determinant factors in bacterium shedding (Bane et al., 2001). Those factors may probably have influenced the differences between the frequencies of pigs shedding the bacterium observed in both farms. The overall incidence density rate was 1.21 per 100 pig-week at risk. This means that for every 100 pigs at risk 1.21 shed L. intracellularis every week.

The lack of significant differences in body weight gain between positive and negative pigs $(\mathrm{P}>0.05)$ may be partly explained, because the study design does not allow to detect a transient negative influence of the infections on the body weight gain compensated by an increased growth in the period following infection. Despite subclinical infection with $L$. intracellularis influencing the body weight gain, this pathogen still might have a great economical impact, e.g. a decreased feed efficiency, acute outbreaks in native herds, medication and prophylaxis.

In conclusion the shedding of the bacterium occurred during the whole period of study. At least in this study, L. intracellularis could not be used to predict the effect of the pathogen on body weight gain.

Keywords: pig, porcine proliferative enteropathy, Lawsonia intracellularis, longitudinal study

\section{RESUMO}

Avaliou-se a distribuição de Lawsonia intracellularis em fezes de suínos, coletadas diretamente no reto, durante a fase de crescimento/terminação, sob condições de campo, e determinou-se o efeito da infecção L. intracellularis no ganho de peso. O estudo epidemiológico longitudinal foi desenvolvido em uma granja de múltiplos sítios em Yucatan, México. A granja possuía três sítios geograficamente isolados com o sistema "todos dentro todos fora". Uma amostra de 56 suínos negativos para a bactéria foi calculada utilizando prevalência esperada de 5\%, nível de confiança de $95 \%$ e população de 2000 suínos terminados. Os suínos foram amostrados 12 vezes desde o nascimento até a $23^{a}$ semana de idade. A detecção de DNA bacteriano nas fezes pela técnica de reação em cadeia pela polimerase em qualquer coleta representou um caso. Dos 56 suinos monitorados, 13 eliminaram L. intracellularis nas fezes $e$ somente um resultou positivo duas vezes. A eliminação de L. intracellularis foi detectada desde a terceira até a $19^{a}$ semana de idade, observando-se maior número de animais positivos na $11^{a}$ semana. A incidência acumulada e a taxa de incidência foram 23,2\% e 1,21 suínos por 100 animais/semana em

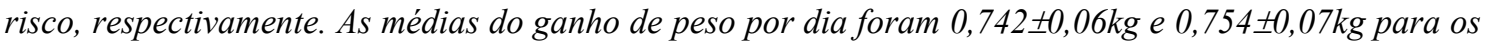
suínos negativos e positivos, respectivamente $(P>0,05)$. A eliminação da bactéria ocorreu durante todo o período de estudo. Pelo menos neste estudo, L. intracellularis não pode ser utilizado para predizer o efeito da bactéria sobre o ganho de peso.

Palavras-chave: suíno, enteropatia proliferativa, Lawsonia intracellularis, estudo longitudinal 


\section{REFERENCES}

GARCÍA, E. Modificaciones al sistema de clasificación climática de Koeppen. México, DF: Instituto de Geografía, Universidad Nacional Autónoma de México, 1988. 276p.

LAWSON, G.H.K.; GEBHART, C.J. Review: Proliferative enteropathy. J. Compend. Pathol., v.122, p.77-100, 2000.

MAPHOTER, M.E.; JOENS, L.A.; ROBERTS, L. Experimental reproduction of porcine proliferative enteritis. Vet. Rec., v.121, p.533536, 1987.

MARTIN, W.S.; MEEK, A.; WILEBERG. Veterinary epidemiology principles and methods. Ames: Iowa State University, 1987. p 48-78.

MCORIST, S.; BOID, R.; LAWSON, G.H.K. Antigenic analysis of Campylobacter species and an intracellular Campylobacter-like organism associated with porcine proliferative enteropathies. Infec. Immun., v.57, p.957-962, 1989.

MCORIST, S.; GEBHART, C.; BOID, R.; BARNS S.M. Characterización of Lawsonia intracellularis, the obligately intracelularis bacterium of porcine proliferative. Int. J. Syst. Bacteriol., v.45, p.820-825, 1995.

MCORIST, S.; GEBHART, C.J. Porcine proliferative enteropathies. In: STRAW, B.E.; D'ALLAIRE, S.; MENGELING, W.L. et al. (Eds.). Disease of swine. 8.ed. Ames: Iowa State University, 1999. p.521-534.

MCORIST, S.; GEBHART, C.J.; LAWSON, G.H.K. Polymerase chain reaction for diagnosis of proliferative enteropathy. Vet. Microbiol., v.41, p.205-212, 1994.

RODRÍGUEZ-GUZMAN, L.E. Patrones de eliminación de Lawsonia intracellularis en cerdos de engorda en una granja de un sitio y otra de sitios múltiples en el estado de Yucatán. 2001. 72f. Tesis (Maestría en Ciencias)-Facultad de Medicina Veterinaria y Zootecnia, Universidad Autonoma de Yucatán, Mérida, Yucatán.

SCHWARTZ, K.; KNITTEL, J.; WALTER, D. et al. Effect of oral tiamulin on the development of porcine proliferative enteropathy in a pureculture challenge model. Swine Health Prod., v.7, p.5-11, 1999.

SMITH, S.H.; MCORIST, S. Development of persistent intestinal infection and excretion of Lawsonia intracellularis by piglets. Res. Vet. Sci., 62, 6-10, 1997.

STEEL R.G.D.; TORRIE, J.H. Bioestadística: Principios y procedimientos. 2.ed. México: McGraw-Hill, 1985. 622 p.

WALTER, D.; KNITTEL, J.; SCHWARTZ, K. et al. Treatment and control of porcine proliferativa enteropathy using different tiamulin delivery methods. Swine Health Prod.,v.9. p109115, 2001.

WINKELMAN, N.; CORNELL P.; BRADFORD J. Feed medication and two water medications against Ileitis caused by Lawsonia intracellularis. In: $28^{\text {th }}$ ANNUAL MEETING OF AMERICAN ASSOCIATION OF SWINE PRACTITIONERS, 8., 1998, Des Moines, Iowa. Proceedings... Des Moines, Iowa, 1998. p.195197. 